СУТНІСТЬ ОПЕРАЦІЙНОГО МЕНЕДЖМЕНТУ ТА ОСНОВНІ ЕТАПИ ЙОГО РОЗВИТКУ

\title{
THE ESSENCE OF OPERATIONAL MANAGEMENT AND THE MAIN STAGES OF ITS DEVELOPMENT
}

удк 339.17

https://doi.org/10.32843/infrastruct44-14

\section{Крамарчук С.П.}

к.е.н., доцент,

доцент каредри менеджменту, публічного управління та персоналу

Тернопільський національний

економічний університет

Лубкей Н.П.

к.е.н., доцент,

доцент кафедри фрінансового

менеджменту та страхування

Тернопільський національний

економічний університет

Kramarchuk Svitlana

Ternopil National Economic University

Lubkey Nadiya

Ternopil National Economic University у статmі досліджено та проаналізовано погляди вітчизняних науковців на визначення поняття сутності операційного менеджменту. Розглянуто різні трактування означеної категорії. Порівняльний аналіз досліджених тлумачень поняття операційного менеджменту виявив недостатню конкретність і чіткість визначень чієї частини менеджменту, тому нами наведене власне визначення сутності операційного менеджменту: операційний менеджмент - це управління процесом створення товарів і надання послуг, що здійснюється на рівні операцій, починаючи із входів, тобто забезпечення підприємства усіма потрібними ресурсами, та супроводжуючи їх транссрормацію у виходи, тобто готові товари і послуги. Основною метою операційного менеджменту визначено досягнення ефективності під час управління будь-якими операціями. Під ефективністю в операційному менеджменті до-цільно розуміти певний заданий ступінь досягнення поставлених перед опе-раційною системою цілей. У статті наведено основні складники операційного менеджменту як виду практичної діяльності з управління організацією, а також досліджено основні етапи його розвитку.

Ключові слова: операційний менеджмент, операції, категорія, по-няття, етапи розвитку, менеджмент, визначення.

В статье исследованы и проанализированы взгляды отечественных ученых на опреде- ление понятия сущности операционного менеджмента. Рассмотрены различные трактовки указанной категории. Сравнительный анализ исследованных толкований понятия операционного менеджмента обнаружил недостаточную конкретность и четкость определений этой части менеджмента, поэтому нами представлено собственное определение сущности операционного менеджмента: операционный менеджмент - это управление процессом создания товаров и оказания услуг, которое осуществляется на уровне операций, начиная с входов, то есть обеспечения предприятия всеми необходимыми ресурсами, и сопровождая их трансформацию в выходы, то есть готовые товары и услуги. Основной челью операционного менеджмента определены достижения эфрфективности при управлении любыми операциями. Под эсрфективностью в операционном менеджменте целесообразно понимать определенную заданную степень достижения поставленных перед операционной системой челей. В статье представлены основные составляющие операционного менеджмента в качестве вида практической деятельности по управлению организацией, а также исследованы основные этапы его развития.

Ключевые слова: операчионный менеджмент, операции, категория, понятие, этапы развития, менеджмент, определение.

In the article the views of domestic scientists on the definition of the essence of operational management are researched and analyzed. Different interpretations of this category are considered. The comparative analysis of the studied interpretations of the concept of operational management revealed their lack of comprehensiveness and clarity. We provide our own definition of the essence of operational management, namely: operational management is the management of the process of creating goods and providing services which is carried out at the level of operations: begins with the inputs to provide the company with all the necessary resources and accompanies their transformation into outputs - finished goods and services. The main purpose of operational management is to achieve efficiency in the management of any operations. Efficiency in operational management is a certain degree of achievement of the goals set for the operating system. The article presents the main components of operational management as a type of practical activities for the management of the organization, namely: management of the processes of creating and designing an operating system; operating system management; operating system quality and performance management; management to ensure the stability of the operating system; management of transformations, changes and development of the operating system. We also studied the main stages of development of operational management, namely: the first stage - the industrial revolution $(1770$ - 1890), the second stage - the development of management theory $(1890$ - 1930); the third stage - the development of scientific management (1930 - present). Each of the stages is described in detail. The outstanding achievements of each period are highlighted. Among them: in 1776 - the development of A. Smith's concept of division of labor; in 1800 - the practical implementation of $E$. Whitney's principle of interchangeability of parts; in 1911 - the generalization of Frederick Taylor's principles of scientific management in his book "Principles of Scientific Management"; in 1913-G. Ford and C. Sorenson created the concept of coordinated conveyor lines; in 1915 - the development of F. Harris mathematical model of the optimal economic size of the purchase. Key words: operational management, operations, category, concepts, stages of development, management, definition.

Постановка проблеми. Сучасне бізнес-середовище, у якому орункціонують підприємницькі структури, динамічно трансорормується. Це фрормує нові вимоги до організацій і викликає появу принципово нових організаційних фрорм підприємництва. Поглиблення економічних реформ, швидкі зміни умов провадження вітчизняного бізнесу та складність у пристосуванні до них зумовлюють потребу дослідження проблем механізму фрункціонування і розвитку сучасних підприємств. Прогресуюча орінансова криза зумовлює потребу формування як практичної, так і теоретичної інфрормаційної бази для подальших ґрунтовних аналітичних досліджень.

Для вітчизняних підприємств притаманним $€$ високий рівень конкуренції. Постійне бажання працювати із максимальною економічною віддачею веде до необхідності удосконалювати і шукати нові шляхи розвитку власної операційної діяльності. За сучасних умов господарювання все більшого значення набуває операційний менеджмент, який забезпечує результативність основної повсякденної діяльності підприємств, що створює реальне підґрунтя для успішної 
реалізації їхніх загальних господарських цілей та місії загалом.

У зв'язку з цим важливим $€$ уточнення сутності такого поняття, як операційний менеджмент, а також дослідження етапів розвитку цього виду менеджменту.

Аналіз останніх досліджень і публікацій. У вітчизняній науковій літературі питання, пов'язані $з$ дослідженням операційного менеджменту, знайшли відображення в численних працях О.В. Ареф'єва, І.О. Бланка, Л. Гелловей, Г.О. Кравченко, Л.О. Лігоненко, Г.В. Митрофранова, Л.П. Наговіциної, М.С. Порядкова, Т.Є. Унковської, Н.М. Ушакової, А.І. Юхименка. Слід зауважити, що майже всі згадані науковці досліджують проблеми, що стосуються виробничої сорери господарювання, залишаючи поза увагою детальне дослідження категорійного апарату.

Постановка завдання. Метою дослідження $€$ уточнення поняття операційного менеджменту та дослідження етапів його розвитку.

Виклад основного матеріалу дослідження. Операційний менеджмент як поняття багатьма науковцями і практиками трактується по-різному. Причиною цього є багатогранність цієї категорії та бажання науковців знайти найбільш вдале визначення.

Зазвичай операційний менеджмент прийнято пов'язувати із виробничою діяльністю чи із фрізичними змінами стану предметів праці. Тому в більшості економічних видань його визначають таким чином: операційний менеджмент - це діяльність 3 управління процесом придбання матеріалів, їхнього перетворення в готовий продукт і постачання цього продукту покупцю [2]. Це визначення, як на нашу думку, так і з погляду багатьох науковців, $€$ досить узагальненим, а також у певному сенсі вузьким. Дослідження спеціальної літератури виявляє явну спрямованість операційного менеджменту на ефрективність та раціональність під час управління будь-якими операціями на підприємстві. 3 огляду на наведене вище визначення, можна відзначити частковий взаємозв'язок визначення операційного менеджменту із визначенням поняття логістики. Проте операційний менеджмент, на нашу думку, $€$ поняттям дещо ширшим. Це важливе вміння, обов'язкове для керівників усіх рівнів та підрозділів підприємства. Оскільки будь-яка діяльність являє собою операції, то операційний менеджмент усіх їх стосується. Саме тому ефективність операцій доцільно розглядати як показники роботи усього підприємства.

Операційний менеджмент полягає в ефективному і раціональному управлінні будь-якими операціями. При цьому варто підкреслити, що ступінь участі фрізичних товарів у цих операціях не важливий. Теорія однаково застосовна як для організацій, що надають послуги, так і для підприємств із виробничою діяльністю.

Група американських авторів дає таке визначення: «Операційний менеджмент - це діяльність, пов'язана з розробленням, використанням і удосконаленням виробничих систем, на основі яких виробляється основна продук-ція чи послуги компанії». У популярній книзі «Основи менеджменту» гово-риться, що терміни операції і виробництво взаємозамінні: «Однак під виробництвом в основному розуміється випуск товарів і переробка сировини. Термін операції ширший, він включає не тільки виробництво товарів, але і надання послуг». I там же: «Операційна функція містить у собі ті дії, у результаті яких виробляються товари і послуги, що поставляються в зовнішнє середовище. Функцію операцій мають всі організації, інакше вони просто не можуть існувати».

O.В. Ареф'єва у своїй науковій праці дає таке визначення: операційний менеджмент (Operations management) - це діяльність, пов'язана 3 розробленням, використанням і удосконаленням виробничих систем, на основі яких виробляються основна продукція або послуги компанії. Операційний менеджмент полягає в ефективному і раціональному управлінні будь-якими операціями [1].

Л. Гелловей визначає операційний менеджмент як усі види діяльності, пов'язані з навмисним перетворенням (трансорормацією) матеріалів, інфрормації або покупців [3]. Тобто операційний менеджмент, на думку науковця, полягає в ефективному і раціональному управлінні будь-якими операціями на підприємстві. При цьому наголошується, що ступінь участі фрізичних товарів у цих операціях не $€$ важливим. Теорія однакова для застосування як для виробничої сорери, так і для сорери послуг.

У праці С.С. Ткачова та Т.П. Іванова наведено такі два визначення операційного менеджменту [8]:

- операційний менеджмент - це діяльність, пов'язана з розробленням, використанням і удосконаленням виробничих систем, на основі яких виробляється основна продукція чи послуги компанії;

- операційний менеджмент - це управління процесами створення товарів та надання послуг посередникам або кінцевим споживачам, що здійснюється на рівні операцій, починаючи із забезпечення організації «входами» (необхідними ресурсами усіх видів) та впродовж їх трансформації у «виходи» (готові товари і послуги).

Як видно 3 викладеного, наведені терміни і поняття мають неоднозначний характер і вимагають уточнення з погляду їхньої коректності і правильного застосування.

Порівняльний аналіз досліджених нами тлумачень поняття операційного менеджменту виявив недостатню конкретність і чіткість визначень 
цієї частини менеджменту. Оскільки операційний менеджмент притаманний кожній організації і $€$ управлінською діяльністю, яка спрямована на виробничі процеси певного підприємства на рівні окремих операцій, нами запропоновано таке визначення цього поняття: операційний менеджмент - це управління процесом створення товарів і надання послуг, що здійснюється на рівні операцій, починаючи із входів, тобто забезпечення підприємства усіма потрібними ресурсами, та супроводжуючи їх трансформацію у виходи, тобто готові товари і послуги.

Основною метою операційного менеджменту $€$ досягнення ефективності під час управління будь-якими операціями. Під ефективністю у операційному менеджменті доцільно розуміти певний заданий ступінь досягнення поставлених перед операційною системою цілей [3; 7].

Операційний менеджмент як вид практичної діяльності з управління організацією включає такі складники, як [4; 6]:

- управління процесами створення та проектування операційної системи;

- управління фрункціонуванням операційної системи;

- управління якістю та продуктивністю операційної системи;

- управління забезпеченням стабільності фрункціонування операційної системи;

- управління перетвореннями, змінами та розвитком операційної системи.

Багато нововведень у операційному менеджменті були розвинуті науковцями-класиками, чий внесок став фундаментом, який сприяв майбутнім досягненням у менеджменті загалом.

Так, Фредерік Тейлор, відомий як батько наукового менеджменту, приділяв велику увагу плануванню, складанню розкладів, добору персоналу, а також іншим сорерам використання трудового потенціалу. Він першим дійшов висновку, що менеджмент як фрорма організації управління виробництвом має бути більш активним та результативним в удосконаленні методів діяльності. Представники школи наукового управління, a саме Фредерік Тейлор, Френк і Ліліан Гілберти та Генрі Гантт, були першими, хто систематично шукав ефективніших шляхів виробництва.

Також у 1913 році Генрі Форд та Чарльз Соренсон поєднали свої знання стосовно стандартизації деталей із конвеєрними лініями та, як наслідок, створили концепцію скоординованих конвеєрних ліній.

Інші класичні наукові досягнення пов'язані із контролем якості. У1924 році Уолтер Шухарт поєднав свої розробки зі статистики з потребами конт-ролю якості та створив підґрунтя для статистичних методів випробувань і контролю якості. Едвард Демінг вважав, як і Фредерик У. Тейлор, що менеджмент має робити більше для удосконалення умов праці, робочих місць і процесів так, щоби це вело до підвищення якості.

Усі ці дослідження та ще багато інших суттєво сприяли підвищенню продуктивності діяльності. Вони у комплексі використовували знання зі статистики, математики, економіки та управління, що дало змогу застосовувати системний аналіз для удосконалення операційних систем.

У розвитку операційного менеджменту можна виокремити три основні історичні етапи:

І етап - промислова революція (1770-1890 рр.) це період значних винаходів у галузі виробництва та послуг, а також прогресивного розвитку виробництва за рахунок його механізації. Основними досягненнями цього етапу можна вважати:

- у 1776 році - розроблення А. Смітом концепції розподілу праці;

- у 1800 році - практичну реалізацію Е. Уітні принципу взаємозамінності деталей.

II етап - розвиток теорії менеджменту (1890-1930 рр.) - період характеризується відокремленням менеджменту у самостійну науку, прискоренням розвитку виробничої діяльності та застосуванням низки технологічних удосконалень. Досягненнями цього період були:

- у 1911 році - узагальнення Фредеріком Тейлором принципів наукового менеджменту в своїй книзі “Принципи наукового управління";

- у 1913 році - створення Г. Фордом i ч. Соренсоном концепції скоординованих конвеєрних ліній;

- у 1915 році - розроблення Ф.Х. Харрісом математичної моделі оптимального економічного розміру закупки;

- у 1916 році - оптимізація виробничих циклів (графріки Генрі Ганта);

- у 1922 році - вивчення робочих рухів Ліліан і Франком Гілберт.

III етап - розвиток наукового менеджменту (1930 р. і до сьогодення) - цей етап характеризується розвитком моделювання та математичних методів прийняття управлінських рішень у операційному менеджменті, а також комплексною автоматизацією виробництва та ссрери послуг. До визначних досягнень третього етапу можна віднести:

- у 1931 році - закладення У. Шухартом статистичного підґрунтя контролю якості;

- у 1938 році - побудову Д.В. Атанасовим першого комп'ютера;

- у 1947 році - розроблення Дж. Данцигом симплекс-методу;

- у 1950-х роках - винайдення А. Фейгенбаумом та У.Е. Демінгом кількісних моделей прийняття рішень під час управління якістю;

- у 1957 році - розроблення М.P. Уокером та Дж.І. Келлі методів сіткового планування PERT/ CPM; 
- у 1960 році - розроблення Д. МакГрегором принципів бездесректного виробництва;

- у 1962 році - розроблення Т. Оно концепції "точно у термін" [8].

Продовженням досягнень цього періоду $\epsilon$ також упровадження новітніх комунікацій на базі інтернет-технологій.

Висновки 3 проведеного дослідження. Загалом у цій статті нами наведене власне бачення стосовно визначення поняття категорії операційного менеджменту та узагальнено основні етапи його розвитку. Нами запропоновано таке визначення цього поняття: операційний менеджмент - це управління процесом створення товарів і надання послуг, що здійснюється на рівні операцій, починаючи із входів, тобто забезпечення підприємства усіма потрібними ресурсами, та супроводжуючи їх транссрормацію у виходи, тобто готові товари і послуги. Також у статті нами досліджено основні етапи розвитку операційного менеджменту: перший етап - промислова революція (1770-1890 роки); другий етап - розвиток теорії менеджменту (1890-1930 роки); третій етап - розвиток наукового менеджменту (1930 р. і до сьогодення). Кожен із етапів у статті детально охарактеризовано та виділено визначні досягнення кожного періоду. Підсумовуючи усе вищевикладене, ми можемо констатувати, що уточнення теоретичних основ операційного менеджменту $є$ актуальним, воно фрормує базу для подальших практичних досліджень у цій сорері.

\section{БІБЛІОГРАФІЧНИЙ СПИСОК:}

1. Ареф'єва О.В. Організаційно-економічні проблеми управління виробничих системами. Харків: Основа, 1996. 263 с.

2. Василенко В.О., Ткаченко Т.І. Виробничий (операційний) менеджмент: Навчальний посібник. За редакцією В.О. Василенка. Київ: ЦУЛ, 2003. 532 с.

3. Гэлловэй Л. Операционный менеджмент. СПб.: Питер, 2002. 320 c.

4. Капінос Г.І. Операційний менеджмент: навчальний посібник. К. : Центр учбової літератури, 2013. $352 \mathrm{c}$.

5. Копчикова І.В. Сутність та основні напрямки розвитку операційної діяльності торговельних мереж. Вісник Чернігівського державного технологічного університету. № 3 (75), 2014. С. 141-148.

6. Плотніченко С.Р., Безверхня Ю.В. Операційний менеджмент в системі управління підприємством.
Збірник наукових праць Таврійського державного агротехнологічного університету (економічні науки). № 1(30), 2016. С. 59-61.

7. Рябчикова Д.А., Коваленко Н.В. Операційний менеджмент сучасного підприємства. Дні науки-2017: Збірник матеріалів IX регіональної науково-практичної консреренції, 16-17 травня 2017 р., Покровськ: Індустріальний інститут ДВНЗ ДонНТУ, 2017. 295 с. С. 151-153.

8. Ткачова С.С., Іванова Т.П. Операційний менеджмент. Навчальний посібник. Харків 2009. $452 \mathrm{c}$.

\section{REFERENCES:}

1. Aref'yeva O.V. (1996) Orhanizatsiyno-ekonomichni problemy upravlinnya vyrobnychykh systemamy. [Organizational and economic problems of production systems management]. Kharkiv: Osnova. 263 p. (in Ukrainian)

2. Vasylenko V.O., Tkachenko T.I. (2003) Vyrobnychyy (operatsiynyy) menedzhment: Navchal'nyy posibnyk. [Tkachenko TI Production (operational) management]. Kyyiv: TSUL, 532 p. (in Ukrainian)

3. Héllovéy L. (2002) Operatsyonnyy menedzhment. [Operations management]. SPb.: Pyter, 320 p. (in Russian)

4. Kapinos H. I. (2013) Operatsiynyy menedzhment: navchal'nyy posibnyk. [Operations management]. K. : Tsentr uchbovoyi literatury, 352 p. (in Ukrainian)

5. Kopchykova I.V. (2014) Sutnist' ta osnovni napryamky rozvytku operatsiynoyi diyal'nosti torhovel'nykh merezh. [The essence and main directions of development of operational activity of trade networks]. Visnyk Chernihivs'koho derzhavnoho tekhnolohichnoho universytetu. № 3 (75), pp.141-148. (in Ukrainian)

6. Plotnichenko S.R., Bezverkhnya YU.V. (2016) Operatsiynyy menedzhment $v$ systemi upravlinnya pidpryyemstvom. [Operational management in the enterprise management system]. Zbirnyk naukovykh prats' Tavriys'koho derzhavnoho ahrotekhnolohichnoho universytetu (ekonomichni nauky). № 1(30), pp. 59-61. (in Ukrainian)

7. Ryabchykova D.A., Kovalenko N.V. (2017) Operatsiynyy menedzhment suchasnoho pidpryyemstva. [Operational management of a modern enterprise]. Dni nauky-2017: Zbirnyk materialiv IKH rehional'noyi naukovo-praktychnoyi konferentsiyi, 16-17 travnya 2017 r., Pokrovs'k: Industrial'nyy instytut DVNZ DonNTU, 295p., pp. 151-153. (in Ukrainian)

8. Tkachova S.S., Ivanova T.P. (2009) Operatsiynyy menedzhment. [Operational management]. Navchal'nyy posibnyk. Kharkiv $452 \mathrm{~s}$. (in Ukrainian) 